\title{
TINJAUAN KARAKTER SHELTER SEMENTARA SEBAGAI UPAYA MITIGASI BENCANA BAGI KORBAN BENCANA ALAM
}

\author{
Nadhifia Iryadini R.A, G. Prasetyo Adhitama \\ (Email:nadh.iryadini@gmail.com) \\ Program Studi Magister Desain \\ Fakultas Seni Rupa dan Desain \\ Institut Teknologi Bandung \\ Jl. Ganesa 10, Bandung, Indonesia
}

\begin{abstract}
ABSTRAK
Indonesia adalah negara yang memiliki potensi tinggi terhadap ancaman bencana alam. Badan Nasional Penanggulangan Bencana (BNPB) mencatat bahwa jumlah bencana alam yang terjadi selama 2018-2019 mengalami peningkatan. Banyak yang kehilangan rumah, harta benda, serta fasilitas-fasilitas umum. Hal tersebut berdampak langsung terhadap psikologis korban, sehingga dalam kondisi trauma, tempat-tempat berlindung sementara sangat dibutuhkan oleh korban paska bencana. Shelter memiliki peran penting untuk mengurangi resiko kematian dan kerentanan serta memperkuat ketahanan masyarakat. Shelter sementara ditujukan sebagai salah satu upaya pemulihan yang menjembatani masa transisi antara fase tanggap darurat dan masa rekonstruksi selesai dilakukan. Penyediaan shelter sementara diharapkan dapat memperingan penderitaan korban bencana serta melindungi korban dari bencana dimasa yang akan datang, namun kebutuhan dan hak-hak korban banyak yang tidak terpenuhi. Penelitian ini bertujuan untuk menjelaskan dan menghasilkan temuan terkait karakter shelter sementara bagi korban bencana alam dalam memenuhi kebutuhan penghuninya. Pada penelitian ini penulis menggunakan metode kualitatif deskriptif. Pengumpulan data dilakukan dengan teknik observasi, wawancara dan melalui data sekunder. Proses metode analisis data dilakukan dengan cara komparasi setiap aspek yang diteliti dan melihat pola hubungannya kemudian mengaitkan temuan dengan upaya mitigasi bencana. Analisis struktur relasi ruang dilakukan dengan metode analisis Space Syntax. Hasil dari penelitian ini menghasilkan beragam karakter shelter sementara, antara lain adalah aspek jenis dan bentuk, hasil yang ditemukan bahwa terdapat 2 organisasi bentuk yang diterapkan pada shelter sementara yaitu bentuk linear dan bentuk terklaster, ukuran shelter mencukupi kebutuhan kapasitas untuk satu keluarga (4-5 orang), kemudian program ruang yang diterapkan adalah ruang private dan ruang publik, sedangkan pada aspek aksesibilitas, terdapat 3 jenis konfigurasi ruang yang menghasilkan bahwa ruang $A$ (ruang publik) memiliki akses yang mudah dijangkau, material bangunan yang digunakan yaitu material alam dan material bangunan, serta pada sistem konstruksi menggunakan sistem bangunan tahan gempa dan sistem knockdown sehingga dapat dibongkar pasang karena sifatnya sementara.
\end{abstract}

Kata kunci : bencana alam, korban bencana, shelter sementara, mitigasi bencana

\section{ABSTRACT}

Indonesia is a country with high potential against the threat of natural disasters. Badan Nasional Penanggulangan Bencana (BNPB) noted that the number of natural disasters occurring during 2018-2019 has increased. Many lost their homes, property, and public facilities. It has a direct impact on the psychological condition of the victim, therefore temporary shelters are urgently needed by the victims after the disaster. Shelter has an important role to play in reducing the risk of death and vulnerability and 
strengthening community resilience. Temporary shelter is intended as one of the recovery efforts that bridges the transition period between the emergency response phase and the reconstruction period completed. The provision of temporary shelter is expected to alleviate the suffering of disaster victims and protect victims from future disasters, but the needs and rights of many victims are not fulfilled. This research aims to explain and produce findings related to the character of temporary shelters for victims of natural disasters in meeting the needs of their residents. In this research the authors used descriptive qualitative methods. Data collection is done by observation techniques, interviews and through secondary data. The process of data analysis method is done by comparing each aspect studied and looking at the pattern of relationship then linking the findings with disaster mitigation efforts. Analysis of the structure of space relationships is done by the Space Syntax analysis method. The results of this research produced a variety of temporary shelter characters, among others are aspects of type and shape, the results found that there are 2 organizations of shapes applied to temporary shelters, namely linear shapes and classified shapes, shelter sizes meet the capacity needs for one family (4-5 people), then the space programs applied are private spaces and public spaces, while in the accessibility aspect, there are 3 types of space configurations that result in that space $A$ (public space) has easy access to, building materials used are natural materials and building materials, as well as in construction systems using earthquake-resistant building systems and knockdown systems so that they can be dismantled because of their temporary nature.

Keywords : natural disasters, disaster victims, temporary shelters, disaster mitigation

\section{PENDAHULUAN}

Indonesia merupakan salah satu negara yang sering dilanda bencana. Data dan infografis update terbaru oleh BNPB (Badan Nasional Penanggulangan Bencana) mengenai bencana alam yang telah terjadi di Indonesia mengungkapkan bahwa jumlah kejadian bencana alam di Indonesia dari tahun 2018-2019 mengalami peningkatan yang cukup tinggi. Bencana alam yang sudah terjadi di tahun 2019 antara lain adalah puting beliung, kebakaran hutan dan lahan, banjir, tanah longsor, kekeringan, gempa bumi, gelombang pasang dan abrasi, serta erupsi gunung berapi. Kondisi tersebut menyebabkan Indonesia menjadi salah satu negara yang memiliki potensi tinggi terhadap ancaman bencana alam.

Meskipun bencana di Indonesia sudah sering terjadi, pemerintah serta berbagai stakeholder di dunia yang berwenang memberikan bantuan seringkali tidak dapat berlangsung. Proses penanggulangan bencana menjadi harapan bagi korban bencana dalam menghadapi dan menerima kenyataan yang telah terjadi. Sebagaimana didefinisikan dalam UU 24 Tahun 2007 tentang Penanggulangan Bencana, penyelenggaraan Penanggulangan Bencana adalah serangkaian upaya yang meliputi penetapan kebijakan pembangunan yang berisiko timbulnya 
bencana, kegiatan pencegahan bencana, tanggap darurat, dan rehabilitasi. Penyediaan shelter sementara diharapkan dapat menjadi upaya tanggap darurat untuk memperingan penderitaan korban bencana alam. Tidak dipungkiri bahwa bantuan shelter atau hunian menjadi salah satu faktor penentu keberlangsungan hidup setelah bencana, terutama bagi kelompok rentan, seperti bayi dan balita, lansia, penyandang disabilitas, korban yang sakit atau luka, dan orang lanjut usia.

Menurut Affisa (2014), pembangunan hunian sementara ditujukan sebagai salah satu upaya pemulihan yang menjembatani masa transisi antara fase tanggap darurat dan masa rekonstruksi, namun dalam hasil penelitiannya menyebutkan bahwa, tingkat penerimaan penghuni terhadap program hunian sementara (huntara) Merapi 2010 hanya mencapai 67\%. Kecilnya presentase kepuasan banyak dipengaruhi oleh kualitas huntara mulai dari birokrasi yang menyebabkan keterlambatan pengerjaan, kualitas hunian, partisipasi, dan yang terpenting adalah kepercayaan penghuni terhadap program ekonomi dan kepastian penghidupan dimasa depan. Kehilangan harta benda serta rumah tinggal secara mendadak berpengaruh terhadap psikologis korban, seperti yang dikemukakan oleh Levine, Goldman, \& Cooper (1972) yang dikutip oleh Taft (1977) menyatakan bahwa paparan ke lingkungan baru dapat menyebabkan stress serta meningkatkan reaksi fisiologis tubuh yang dapat menyebabkan disfungsi dalam peningkatan aktivitas hipofisis-adrenal (Winkelman, 1994), dampak tersebut dapat dirasakan pada korban bencana alam jika lingkungan baru tidak dapat memenuhi kebutuhan mereka. Beberapa permasalahan dalam shelter sementara yang ditemukan oleh penulis adalah kurang adanya kepastian waktu pemberian shelter tetap, sehingga banyak korban bencana alam yang harus tinggal di shelter sementara dalam waktu yang cukup lama (Affisa dan Djunaedi, 2014), material bangunan yang tidak tahan lama, seperti pada salah satu shelter sementara di Banten, penghuni mengeluhkan bahwa atap rumah bocor saat musim hujan (iNews, 2019), serta masalah kenyamanan dan keamanan, seperti yang terjadi pada salah satu shelter sementara di Lombok NTB yang tergenang banjir disaat musim hujan, sehingga korban harus mengungsi kembali ke tempat lain (Rasyid, 2018). 
Melihat dari permasalahan diatas, menunjukkan bahwa pemberian shelter sementara masih kurang memperhatikan kualitas hunian dan bencana di masa yang akan datang. Jika tidak diperbaiki maka permasalahan tersebut dapat membuat korban paska bencana sulit bertahan dan pulih kembali. Berdasarkan kondisi tersebut, kebutuhan shelter sementara yang selama ini ada di Indonesia masih perlu dikaji lebih dalam lagi, oleh karena itu penulis ingin mencari tahu karakter shelter sementara yang layak, aman, dan dapat memenuhi kebutuhan pengguna. Tujuan dari penelitian ini adalah menjelaskan jenis dan karakter shelter sementara bagi korban bencana alam, kemudian mencari apa saja aspek-aspek yang masih belum dapat memenuhi kebutuhan penghuni, sehingga dari aspek tersebut akan ada temuan terkait karakter shelter sementara dalam memenuhi kebutuhan penghuni, kemudian dikaitkan dengan upaya mitigasi bencana agar korban nantinya dapat bertahan dan pulih kembali dalam kondisi stabil secara bermartabat. Hasil dari penelitian ini diharapkan dapat menjadi acuan bagi departemen / instansi / lembaga terkait serta lembaga non pemerintah dan stakeholder diseluruh dunia dalam membangun sebuah shelter sementara di masa yang akan datang.

\section{METODE PENELITIAN}

Penelitian ini dilakukan dengan metode kualitatif deskriptif yang mengkaji karakter sebuah bangunan shelter sementara yang selama ini diberikan kepada korban bencana untuk mencari aspek-aspek apa saja yang belum memenuhi kebutuhan korban, dan diharapkan dapat menjadi acuan perbaikan shelter sementara dimasa depan dalam memenuhi kebutuhan penghuni. Pendekatan analisis deskriptif dengan cara pemaparan hasil-hasil temuan dari penelitian yang dilakukan dengan hasil-hasil temuan dari literatur terdahulu untuk menentukan berbagai persamaan dan perbedaan pada hasil temuan.

Sampel yang diteliti adalah shelter sementara, yaitu hunian sementara yang dibangun untuk korban bencana alam yang kehilangan rumah tinggal karena tertimpa bencana. Jumlah sampel yang diambil berjumlah 8 shelter sementara di beberapa kota di Indonesia yang terdampak bencana antara lain adalah, Yogyakarta, Palu, Lombok, dan Banten. Sementara itu, variabel penelitian pada penelitian ini antara lain adalah jenis bencana, ukuran, kapasitas, fasilitas, bentuk dan jenis, relasi ruang, bukaan, warna, material, dan sistem konstruksi. Variabel penelitian tersebut merupakan unsur rupa dan ciri visual bangunan yang digunakan untuk mencari karakter pada shelter sementara dengan cara mengevaluasi fisik bangunan, dan organisasi bagian-bagian bangunannya. 
Pengumpulan data dilakukan dengan teknik observasi langsung di lapangan untuk mendapatkan data berupa foto dan gambar lapangan, kemudian untuk mendapatkan informasi yang lebih mendalam dilakukan wawancara terbuka dengan informan kunci serta narasumber, wawancara juga dilakukan dengan praktisi dan pemerhati bencana yang pernah melakukan kegiatan sosial untuk bencana alam. Selain itu diperlukan beberapa data sekunder berupa literatur, jurnal, buku panduan terkait dengan bencana, dan berita faktual melalui media elektronik, serta youtube untuk menggali informasi dan data lebih dalam lagi.

Selanjutnya metode analisis data dilakukan dengan cara komparasi setiap aspek yang diteliti dan melihat pola hubungannya kemudian mengaitkan temuan dengan upaya mitigasi bencana. Analisis struktur relasi ruang dilakukan dengan metode analisis Sspace Ssyntax. Space Syntax adalah teori yang dikembangkan untuk mengungkapkan jenis fitur spasial yang tersembunyi didalam pola spasial, ia memiliki tujuan menguraikan baik struktur relasional ruang dan tampil sebagai pendekatan yang mencakup metode ilmiah, digital dan berbasis grafis (Hillier dan Hanson, 1984; Hillier, 1996). Metode analisis Space Syntax dalam penelitian ini digunakan untuk mengungkap atau menjelaskan aksesibilitas ruang dalam shelter sementara melalui kode, sehingga akan diketahui struktur relasional tiap ruang tersebut dan maknanya.

\section{Rumah Atau Pemukiman}

Rumah merupakan salah satu kebutuhan dasar manusia disamping pangan, sandang, pendidikan dan kesehatan. Rumah adalah bangunan yang berfungsi sebagai tempat tinggal atau hunian dan sarana binaan keluarga (Turner, 1982). Maslow menyusun hierarki kebutuhan manusia berkaitan dengan hunian atau rumah berdasarkan tingkatan tertentu dimulai dari yang terbawah atau paling mendasar yaitu rumah dinilai memberikan perlindungan terhadap gangguan alam dan binatang yang berfungsi sebagai tempat tinggal, tidur, dan pemenuhan kebutuhan badani, rumah dinilai harus bisa menciptakan rasa aman, sebagai tempat menjalankan ritual, penyimpanan harta milik berharga, dan menjamin hak pribadi, selain itu dapat memberikan peluang untuk berinteraksi dan aktivitas komunikasi yang akrab dengan lingkungan sekitar (teman, tetangga, ataupun keluarga), serta memberikan peluang untuk tumbuhnya harga diri, yang disebut Pedro Arrupe sebagai "Status Conferring Function", yakni kesuksesan seseorang tercermin dari rumah dan lingkungan tempat huniannya. 
Maka berdasarkan penjelasan di atas, rumah merupakan kebutuhan dasar yang harus terpenuhi baik secara kualitas maupun kuantitas yang merupakan bagian yang tidak terpisahkan dari kehidupan penghuninya, yang idealnya direncanakan sesuai keinginan, dan budaya setempat, serta berkembang sesuai sumber daya, dan kebutuhan ruang sesuai persepsi penghuni. Pemukiman ada karena terbentuknya kesatuan diantara manusia dan lingkungan. Menurut Constantinos A. Doxiadis (1968: 2135) dalam Surtiani (2006) ada lima elemen dasar permukiman : a.) Nature (alam), b.) Man (manusia), c.) Society (masyarakat), d.) Shells (rumah), e.) Networks (jaringan atau sarana prasarana).

Selain itu, Rapoport (1969) dalam bukunya House Form and Culture mengidentifikasi bahwa terdapat lima aspek budaya yang tercermin dalam desain sebuah rumah, yaitu : a.) Cara menjalankan aktivitas dasar, b.) Struktur keluarga, c.) Peran gender, d.) Sikap terhadap privasi, dan e.) Proses sosial. Berdasarkan uraian diatas maka dapat disimpulkan bahwa karakter sebuah rumah atau pemukiman berkembang dan terkait dengan budaya dan lingkungan di sekitar penghuni. Rumah menjadi salah satu kebutuhan yang sangat penting bagi manusia karena menjadi penunjang dalam berkelanjutan hidup manusia.

\section{Teori Tipologi Dan Bentuk}

Teori tipologi menurut Sukada (1989), Tipologi adalah penelusuran asal-usul terbentuknya objek-objek arsitektural yang terdiri dari tiga tahap, yaitu:

a. Menentukan "bentuk - bentuk dasar" (formal structure) yang ada dalam tiap objek arsitektur.

b. Menentukan "sifat-sifat dasar" (properties) yang dimiliki oleh setiap objek arsitektural berdasarkan bentuk dasar yang ada padanya.

C. Mempelajari proses perkembangan bentuk dasar tersebut sampai pada perwujudannya saat ini. Menurut Johnson (1994), tipologi adalah kajian tipe. Tipe berasal dari kata typos (Yunani) yang berarti impresi, gambaran, atau figur dari suatu objek. Secara umum, tipe sering digunakan untuk menjelaskan bentuk keseluruhan, struktur, atau karakter dari suatu bentuk atau objek tertentu. Menurut Rossi (1982), jika ditinjau dari objek bangunan, tipologi terbagi atas tiga hal pokok, yaitu site (tapak) bangunan, form (bentuk) bangunan, dan organisasi bagian-bagian bangunan tersebut. Berdasarkan teori tersebut, dapat diartikan bahwa tipologi adalah suatu ilmu yang mempelajari segala sesuatu tentang tipe.

Hal ini berarti ada satu tipe-tipe tertentu dari suatu bangunan yang akan membentuk satu karakter, ciri, atau image yang dapat dijadikan acuan untuk dapat dikelompokkan seperti bentuk, skala, warna, tekstur, potongan-potongan bidang maupun ruang (Suharjanto, 2013). Tipologi arsitektur atau dalam 
hal ini tipologi bangunan erat kaitannya dengan suatu penelusuran elemen-elemen pembentuk suatu sistem objek bangunan atau arsitektural. Teori tipologi dalam penelitian ini digunakan untuk mengklasifikasikan data melalui kesamaan bentuk, struktur, dan karakter dari bangunan shelter sementara.

Menurut Francis D.K Ching (2008), bentuk seringkali menyertakan sebuah indera massa atau volume yang tiga dimensional, maka bentuk-bentuk dasar lebih terujuk secara khusus pada aspek bentuk yang sangat penting yang mengendalikan penampilannya. Bentuk dasar memiliki sifat visual sebagai berupa ukuran, warna, dan tekstur.

Francis D.K Ching (2008) menambahkan bahwa didalam arsitektur, kita lebih memperhatikan bentukbentuk dasar yang berupa bidang lantai, dinding, dan langit-langit yang menutup ruang, bukaanbukaan pintu dan jendela di dalam suatu keberdekatan spasial, serta siluet dan kontur suatu bentuk bangunan. Berdasarkan penjelasan diatas maka unsur rupa dan ciri visual bentuk digunakan penulis sebagai variabel penelitian yang akan diselidiki lebih dalam pada penelitian ini untuk mencari tipologi dan karakter pada bangunan.

\section{PEMBAHASAN}

Shelter sementara adalah bantuan dari pemerintah/lembaga terkait dan lembaga non pemerintah dengan konsep hunian yang digunakan untuk sementara sebelum korban paskabencana relokasi ke shelter tetap, maka sebelum masuk pada analisis shelter sementara, penulis mencari tahu asal-usul terbentuknya sebuah objek untuk mencari tahu karakteristik shelter sementara. Berikut ini adalah perolehan data shelter sementara yang selama ini ada di Indonesia yang dapat penulis klasifikasi yang dibagi dalam beberapa aspek bangunan kemudian dikelompokkan dalam bentuk tabel : 
Serat Rupa Journal of Design, July 2021, Vol.5, No.2: 271- 295

E-ISSN: 2477-586X, ISSN: 2338-3348 | https://doi.org/srjdv5i2.3014| Received: 06-10-2020 Accepted: 16-07-2021

Nadhifia Iryadini R.A, G. Prasetyo Adhitama

Tinjauan Karakter Shelter Sementara Sebagai Upaya Mitigasi Bencana Bagi Korban Bencana Alam

Tabel 1. Data Shelter Sementara

\begin{tabular}{|c|c|c|c|c|c|}
\hline \multirow{2}{*}{$\begin{array}{l}\text { SHELTER } \\
\text { SEMENTARA }\end{array}$} & \multirow{2}{*}{ FASILITAS } & \multirow{2}{*}{ KAPASITAS } & \multicolumn{3}{|c|}{ RELASI RUANG } \\
\hline & & & CONVEX SPACE & J-GRAPH & RUANG / LAYOUT \\
\hline \multirow{2}{*}{$\begin{array}{l}\text { KORBAN BENCANA } \\
\text { LAHAR DINGIN, } \\
\text { MERAPI YOGYAKARTA }\end{array}$} & \multirow{2}{*}{$\begin{array}{l}\text { TOILET UMUM } \\
\text { DAPUR UMUM } \\
\text { AIR BERSIH } \\
\text { LISTRIK } \\
\text { MUSHOLA UMUM }\end{array}$} & \multirow[t]{2}{*}{1 KELUARGA } & \multirow{2}{*}{$\overbrace{\oplus}^{(B)}$} & \multirow{2}{*}{$\begin{array}{l}-B-\cdots-C \\
\cdots\end{array}$} & $\begin{array}{l}1 \text { RUANG SERBAGUNA } \\
2 \text { KAMAR TIDUR }\end{array}$ \\
\hline & & & & & \begin{tabular}{c|c} 
KAMAR 1 & KAMAR 2 \\
R.SERBAGUNA
\end{tabular} \\
\hline BENTUK & WARNA & BUKAAN & UKURAN & MATERIA & $\begin{array}{c}\text { SISTEM } \\
\text { KONSTRUKSI }\end{array}$ \\
\hline $\begin{array}{l}\text { BENTUK LINIER } \\
\text { RUMAH BAMBU }\end{array}$ & NATURAL & $\begin{array}{l}\text { PINTU UTAMA DAN } \\
\text { JENDELADI SETIAP } \\
\text { SISI BANGUNAN }\end{array}$ & $4 \times 6 \mathrm{M} 2$ & $\begin{array}{l}\text { BAMBU } \\
\text { PETUNG }\end{array}$ & $\begin{array}{c}\text { SISTEM } \\
\text { BONGKAR PASANG } \\
\text { DAN RUMAH } \\
\text { TAHAN GEMPA }\end{array}$ \\
\hline KELEBIHAN & \multicolumn{5}{|c|}{$\begin{array}{l}\text { - MENAMPUNG } 1 \text { KK } \\
\text { - PRAKTIS \& RAMAH LINGKUNGAN } \\
\text { - SISTEM BONGKAR PASANG } \\
\text { - TERDAPAT } 2 \text { KAMAR TIDUR } \\
\text { - TAHAN TERHADAP TERPAAN HUJAN, ANGIN, DAN GEMPA }\end{array}$} \\
\hline KEKURANGAN & \multicolumn{5}{|c|}{$\begin{array}{l}\text { - MATERIAL DINDING TIDAK KEDAP SUARA } \\
\text { - TIDAK ADA TOLLET PRIBADI }\end{array}$} \\
\hline 2014. Mahasiswa UGM & $\begin{array}{l}\text { kan Huntara } \\
\text { iswa-ugm-ke }\end{array}$ & $\begin{array}{l}\text { Pasang". Diambil } \\
\text {-huntara-bongka }\end{array}$ & & & \\
\hline
\end{tabular}


Serat Rupa Journal of Design, July 2021, Vol.5, No.2: 271- 295

E-ISSN: 2477-586X, ISSN: 2338-3348 | https://doi.org/srjdv5i2.3014| Received: 06-10-2020 Accepted: 16-07-2021

Nadhifia Iryadini R.A, G. Prasetyo Adhitama

Tinjauan Karakter Shelter Sementara Sebagai Upaya Mitigasi Bencana Bagi Korban Bencana Alam

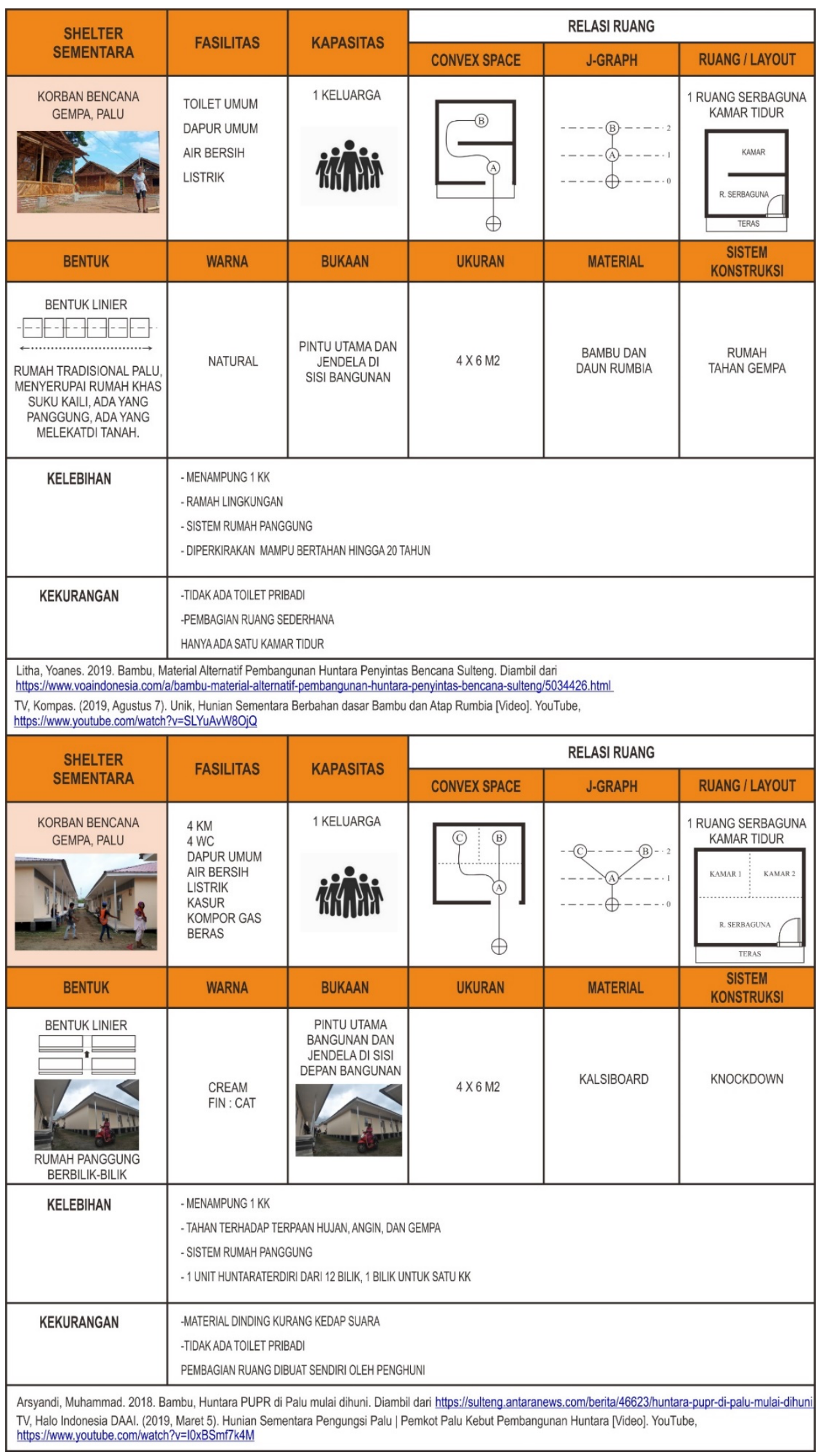


Serat Rupa Journal of Design, July 2021, Vol.5, No.2: 271- 295

E-ISSN: 2477-586X, ISSN: 2338-3348 | https://doi.org/srjdv5i2.3014| Received: 06-10-2020 Accepted: 16-07-2021

Nadhifia Iryadini R.A, G. Prasetyo Adhitama

Tinjauan Karakter Shelter Sementara Sebagai Upaya Mitigasi Bencana Bagi Korban Bencana Alam

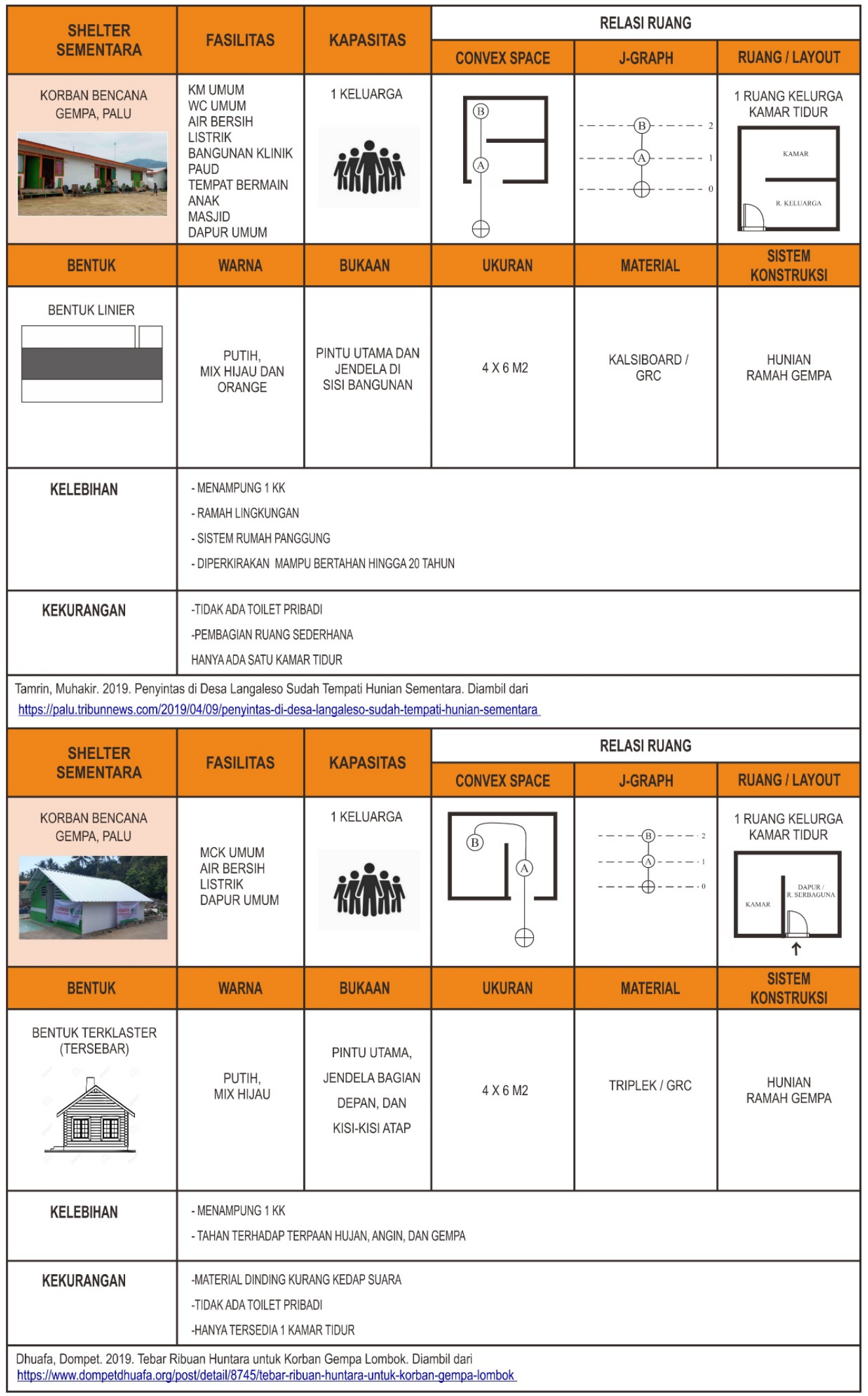


Serat Rupa Journal of Design, July 2021, Vol.5, No.2: 271- 295

E-ISSN: 2477-586X, ISSN: 2338-3348 | https://doi.org/srjdv5i2.3014| Received: 06-10-2020 Accepted: 16-07-2021 Nadhifia Iryadini R.A, G. Prasetyo Adhitama

Tinjauan Karakter Shelter Sementara Sebagai Upaya Mitigasi Bencana Bagi Korban Bencana Alam

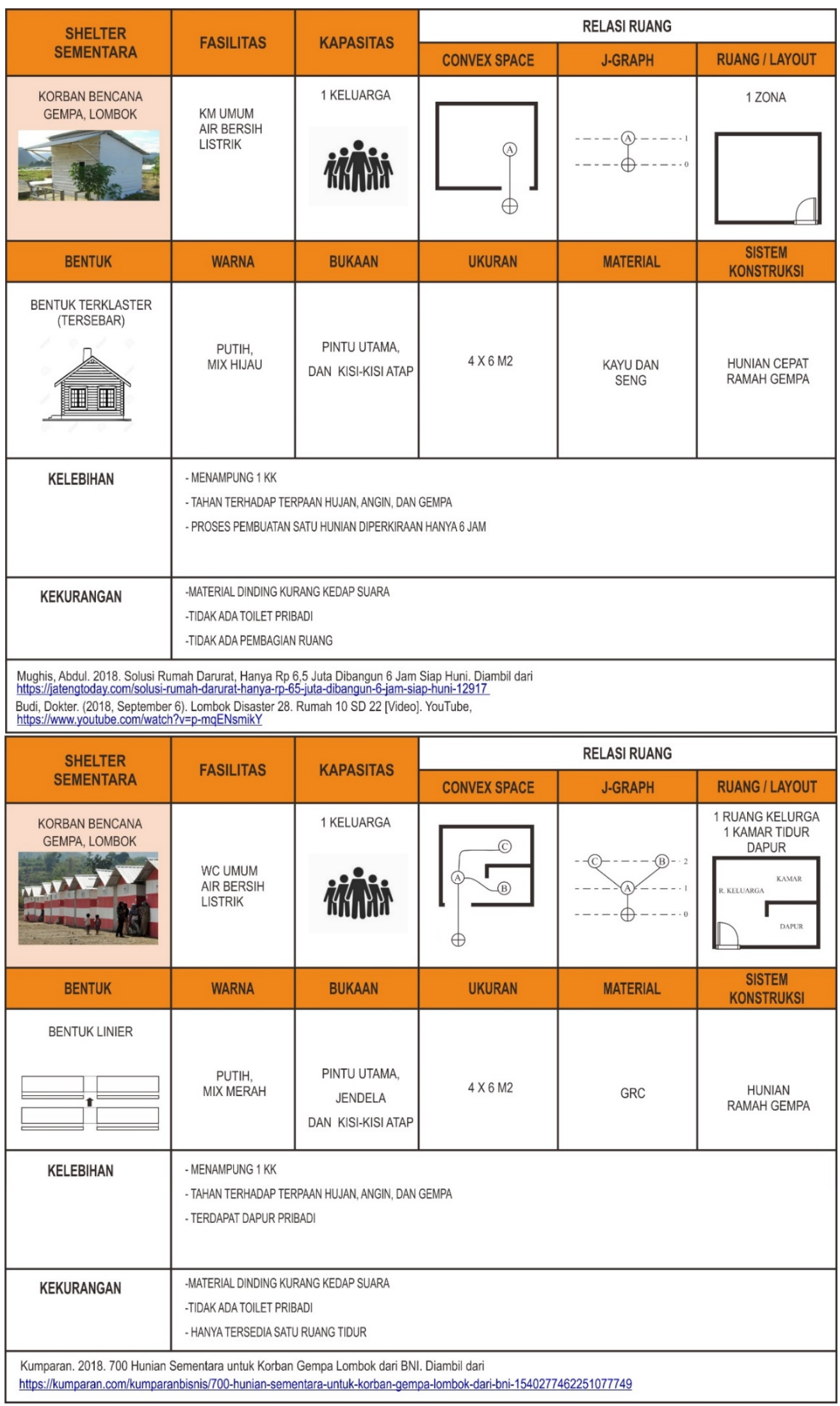




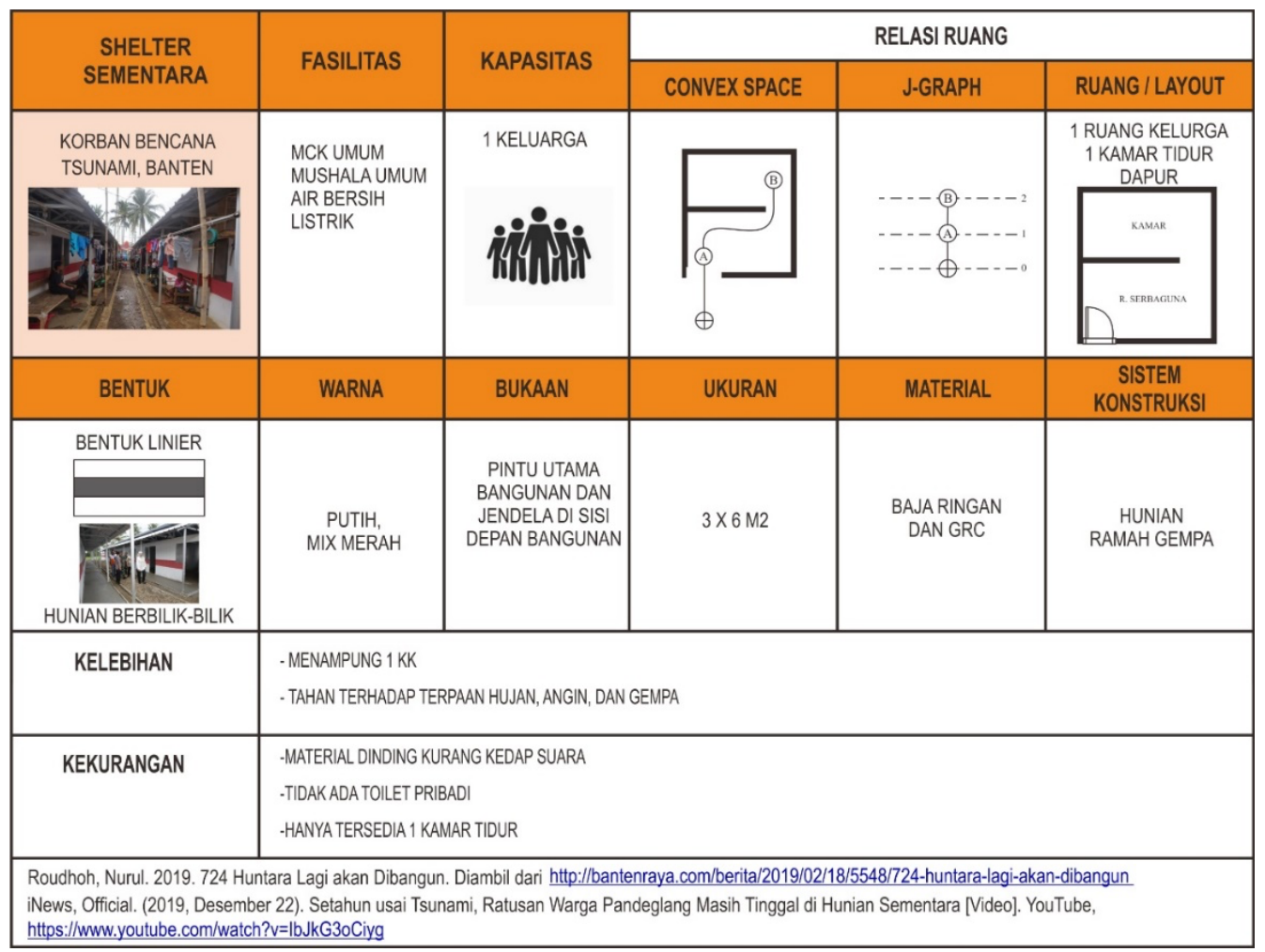

Sumber : Berita faktual melalui media elektronik, dan www.youtube.com

Berdasarkan tabel 1 diatas, terdapat 8 perolehan data shelter sementara yang berada di beberapa kota terdampak bencana alam di Indonesia antara lain ada di :

1. Kota Yogyakarta, bencana lahar dingin Merapi

2. Kota Palu, bencana gempa dan likuifaksi

3. Kota Lombok, bencana gempa, dan

4. Kota Banten, bencana tsunami.

Beberapa aspek yang diselidiki oleh penulis adalah terkait dengan jenis bencana, bentuk dan jenis bangunan, ukuran, kapasitas, fasilitas, relasi ruang, material, bukaan dan sistem konstruksi. Hal tersebut perlu diselidiki karena analisa tipologi bangunan dalam penelitian ini ada pada fase menganalisa tipologi atau karakter bangunan dengan cara mencari bentuk sederhana suatu bangunan melalui pencarian bangun dasar serta sifat dasarnya, maka dari tabel diatas, penulis melakukan analisa data 
dan menghasilkan temuan terkait dengan penyediaan kebutuhan shelter sementara bagi korban bencana alam, antara lain yaitu :

\section{a. Jenis Bencana}

Berdasarkan tabel 1, bencana alam yang di alami oleh korban bencana adalah bencana alam berat seperti gempa bumi, likuifaksi, dan tsunami.

Menurut Panduan untuk Shelter Kemanusiaan, gempa bumi dan tsunami adalah jenis bencana yang terjadi secara cepat. Bencana yang menimpa masyarakat secara mendadak sangat mempengaruhi kemampuan persiapan dan tanggapan dalam memenuhi kebutuhan shelter, seperti :

a. Bencana tsunami

- Penyebab terbesar kehilangan barang-barang rumah tangga dalam jumlah besar dan kekurangan material yang dapat digunakan kembali.

- Akses terbatas terhadap material shelter sehingga merusak rantai suplai

- Dapat melibatkan relokasi sementara dan/atau permanen.

b. Bencana Gempabumi

- Penyebab terbesar kehilangan shelter permanen di Indonesia

- Rentan menyebabkan kerusakan shelter sepenuhnya atau sebagian secara permanen dan dalam skala besar

- Biasanya potensial untuk penggunaan ulang material pembangunan.

Tidak dipungkiri bahwa memang Indonesia menjadi salah satu negara yang rawan akan bencana. Oleh karena itu penyediaan kebutuhan shelter sementara menjadi sangat penting bagi korban bencana dan perlu dipersiapkan secara matang terkait dengan kenyamanan dan keamanan pengguna. Menurut hasil wawancara penulis dengan Dr. Nuraini Rahma Hanifa ahli kegempaan dan sekretaris di Pusat Unggulan Iptek (PUI-PT) Sains dan Teknologi Kegempaan ITB, jangka waktu penggunaan shelter sementara adalah sekitar 6 bulan - 1 tahun, namun kenyataan dilapangan seringkali korban bencana tidak mendapat kepastian bantuan shelter tetap sehingga mereka terpaksa tinggal dalam shelter sementara lebih dari 1 tahun. 


\section{b. Bentuk dan Jenis}

Pada aspek bentuk bangunan, penulis mengkategorikan bentuk-bentuk bangunan shelter sementara ke dalam organisasi bentuk-bentuk aditif. Bentuk-bentuk aditif dihasilkan dari penambahan elemen yang terpisah, dapat dikenali melalui kemampuan mereka tumbuh dan menyatu dengan bentukbentuk lainnya (Ching, 2008). Berikut adalah beberapa organisasi bentuk aditif yang terbentuk di shelter sementara, antara lain adalah :

Tabel 2. Tabel Organisasi Bentuk pada Shelter Sementara

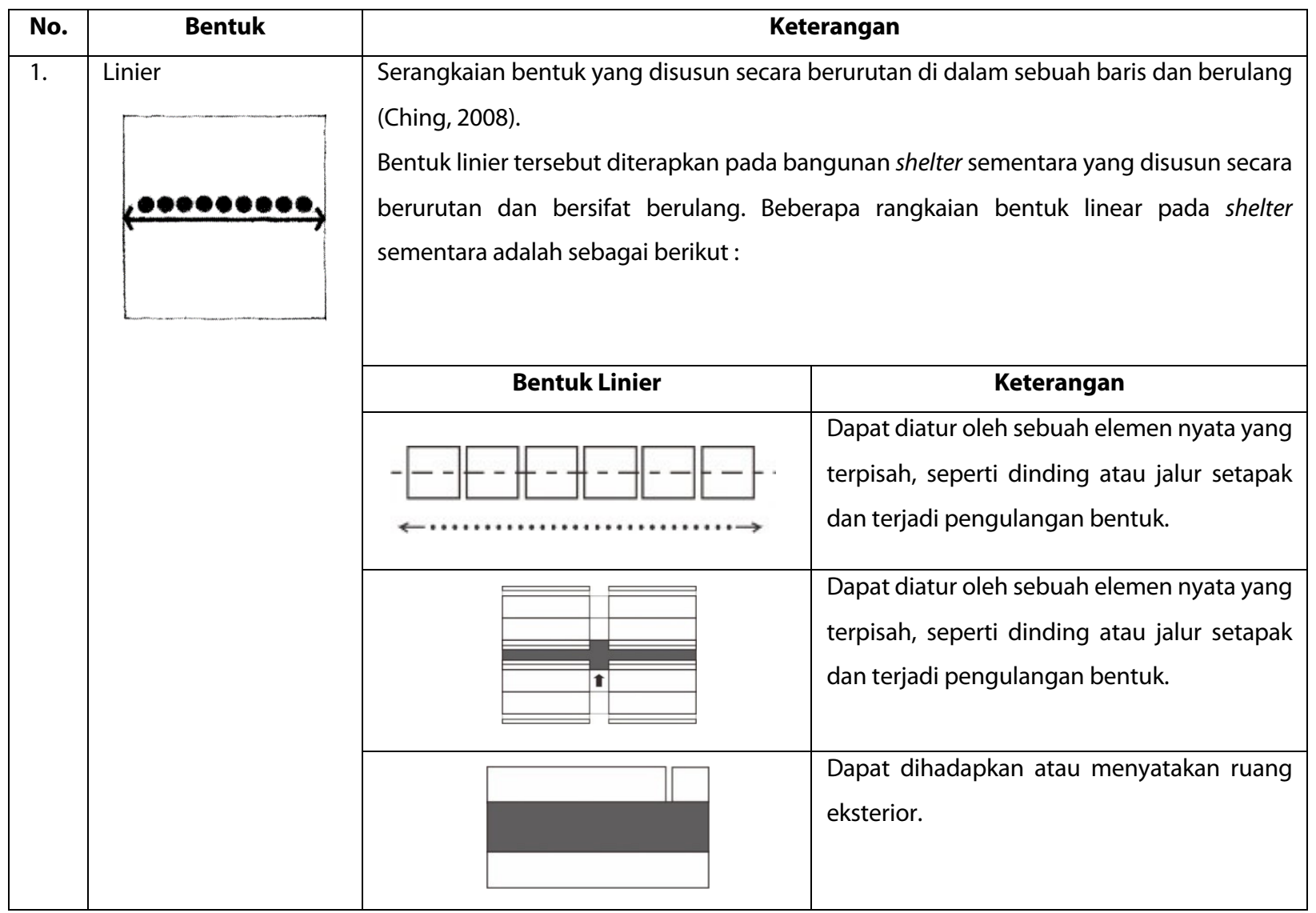




\begin{tabular}{|l|l|l|}
\hline 2. & $\begin{array}{l}\text { Terklaster } \\
\text { (Tersebar) }\end{array}$ & $\begin{array}{l}\text { Suatu koleksi bentuk yang digabungkan bersama oleh keberdekatan atau kesamaan } \\
\text { dalam pembagian karakter visualnya. Organisasi terklaster mengelompokkan bentuk- } \\
\text { bentuknya menurut kebutuhan ukuran, bentuk dasar, atau keberdekatannya (Ching, } \\
\text { 2008). } \\
\text { Bentuk kubus diatas menjadi bentuk induk atau ruang utama yang kemudian di } \\
\text { tempelkan sebuah bentuk tambahan yaitu limas pada permukaan atas bentuk induk, } \\
\text { sehingga menjadi bentuk terklaster. }\end{array}$ \\
\hline
\end{tabular}

Sumber : Arsitektur Bentuk Ruang dan Susunannya, Francis D.K Ching, 2008.

Berdasarkan analisis diatas, organisasi bentuk aditif yang yang banyak diimplementasikan pada shelter sementara adalah organisasi bentuk linier, terdapat 6 shelter sementara yang menerapkan bentuk linier, dimana bentuk shelter sementara disusun berbilik-bilik sehingga terlihat berurutan dalam satu baris dan berulang. Sedangkan 2 diantaranya menerapkan organisasi bentuk terklaster. Bentuk terklaster tidak disusun secara berurutan seperti baris pada bentuk linear. Selain organisasi bentuk, penulis menemukan fakta bahwa terdapat dua jenis rumah yang diterapkan pada shelter sementara antara lain adalah :

Tabel 3. Tabel Jenis Rumah pada Shelter Sementara

\begin{tabular}{|r|l|l|}
\hline No. & \multicolumn{1}{|c|}{ Jenis Rumah } & \multicolumn{1}{c|}{ Keterangan } \\
\hline 1. & $\begin{array}{r}\text { Rumah Tapak (Tunggal) } \\
\text { 2. }\end{array}$ & $\begin{array}{l}\text { Rumah tunggal yang terpisah dengan rumah lain dan bangunannya } \\
\text { menapak langsung dengan tanah. }\end{array}$ \\
\hline & Rumah Adat (Panggung) & $\begin{array}{l}\text { Rumah adat jenis rumah panggung yang dibuat sesuai dengan budaya } \\
\text { setempat dengan bidang lantai yang terangkat dari permukaan tanah. }\end{array}$ \\
\hline
\end{tabular}

Sumber : Dok. Pribadi

Berdasarkan fakta diatas, 4 dari 8 shelter sementara menerapkan desain rumah panggung, namun bidang lantai yang terangkat dari permukaan tanah tidak terlalu tinggi seperti yang ada pada rumah 
panggung tradisional pada umumnya. Dua diantaranya adalah hunian berbilik-bilik dan dua diantaranya lagi adalah hunian tunggal. Salah satu desain shelter sementara berbentuk rumah panggung yang diterapkan di kota Palu menyerupai rumah khas suku Kaili yaitu rumah tradisional Sulawesi Tengah. Hal ini mendasari bahwa dibeberapa daerah tertentu masih menerapkan konsep desain rumah sesuai dengan budaya di daerah terdampak. Selain itu menurut Gross (2015) dalam (Angkasa, 2017) desain rumah panggung memiliki beberapa keunggulan yaitu perlindungan terhadap banjir, memaksimalkan pandangan, perluasan ventilasi, estetika, dan penerapan prinsip pembangunan berkelanjutan.

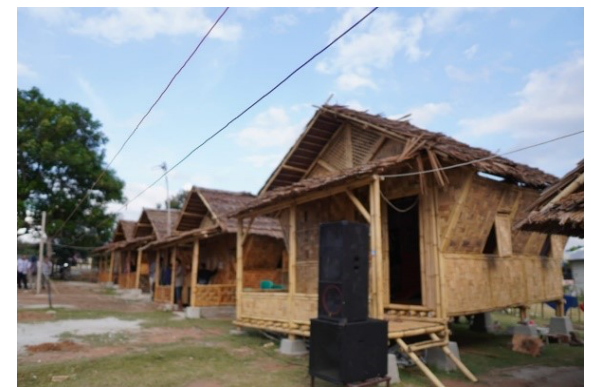

Gambar 1. Shelter Sementara di Kelurahan Poboya, Palu.

Sumber : Yusuf. (2019, Agustus 5). 11 Bulan Pasca Gempa, Pengungsi Poboya Dapat Huntara. Diambil di https://swatvnews.id/2019/08/05/11-bulan-pasca-gempa-pengungsi-poboya-dapat-huntara/

Jika melihat dari keunggulan-keunggulan tersebut, penggunaan konsep rumah panggung pada shelter sementara cukup efektif untuk diterapkan khususnya sebagai perlindungan terhadap banjir, sehingga saat musim hujan shelter sementara dengan konsep rumah panggung akan terhindar dari gangguan banjir. Berdasarkan data yang diperoleh oleh penulis melalui berita faktual dari media elektronik, salah satu shelter sementara yang tidak menerapkan desain rumah panggung di Lombok digenangi banjir akibat hujan lebat. Keadaan ini membuat korban harus mengungsi kembali dan mengalami kesulitan, karena meskipun banjir sudah surut, hunian mereka masih digenangi oleh lumpur.

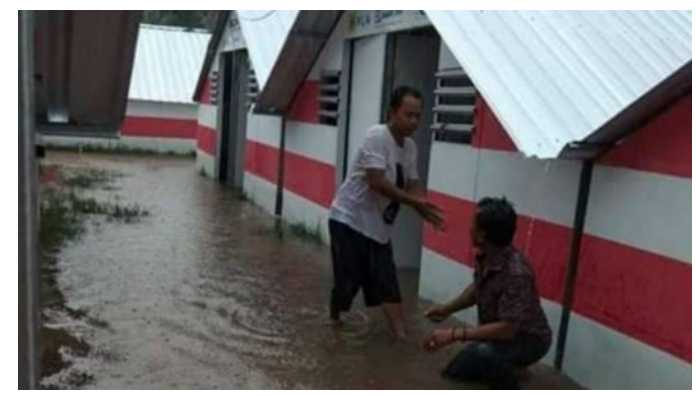

Gambar 2. Shelter sementara di Lombok, NTB Tergenang Banjir

Sumber : Rasyid, Satria Z. (2018, November 9). Huntara Pengungsi Lombok Tergenang Banjir. Diambil dari https://hariannusa.com/2018/11/09/huntara-pengungsi-lombok-tergenang-banjir/ 
Seperti yang jelaskan pada Panduan Shelter untuk kemanusiaan, lokasi dan rancangan shelter harus aman dari risiko lebih lanjut yaitu :

- Jarak yang cukup jauh dari bahaya

- Membuat shelter dengan rancangan dan material yang dapat menangkal bahaya.

Selain itu, shelter harus aman dari bahaya dimasa mendatang, seperti:

- Potensi bencana di masa mendatang, misalnya kebakaran, banjir, dan longsor.

- Reruntuhan bangunan dengan potensi ambruk

- Konflik sosial atau kemungkinan penggusuran dalam jangka waktu tertentu.

Berdasarkan fakta tersebut maka perlu adanya pertimbangan lebih lanjut terkait dengan bentuk desain hunian yang akan diberikan pada korban bencana, sehingga korban merasa aman dan tidak perlu khawatir akan bahaya dimasa mendatang.

\section{c. Ukuran}

Melihat pada tabel 1 terkait dengan ukuran luas bangunan shelter sementara, jika dikaitkan dengan Pedoman Tata Cara Pemberian Bantuan Pemenuhan Kebutuhan Dasar, standar minimal ukuran bantuan hunian sementara adalah berukuran $3 \mathrm{~m}^{2}$ per orang. Maka ukuran luas bangunan shelter sementara sudah mencukupi kebutuhan kapasitas untuk satu keluarga (4-5 orang), namun perlu adanya pertimbangan lebih lanjut bagi keluarga yang memiliki anggota keluarga penyandang disabilitas karena akan membutuhkan ruang yang lebih luas.

\section{d. Program Ruang}

Program ruang yang diterapkan dalam shelter sementara berdasarkan perolehan data penulis terdapat 2 kriteria, yaitu : 
Tabel 4. Program Ruang pada Shelter Sementara

\begin{tabular}{|c|c|c|c|}
\hline No. & Program Ruang & & Keterangan \\
\hline 1. & $\begin{array}{l}\text { Ruang private dan dan ruang publik. } \\
\text { - } 1 \text { kamar tidur (private) } \\
\text { - } 1 \text { ruang serbaguna/ruang keluarga } \\
\text { (publik) }\end{array}$ & KAMAR & $\begin{array}{l}7 \text { dari } 8 \text { shelter sementara memiliki } 1 \\
\text { kamar tidur sebagai ruang private, dan } 1 \\
\text { ruang serbaguna/ruang keluarga sebagai } \\
\text { ruang publik. }\end{array}$ \\
\hline 2. & $\begin{array}{l}\text { Ruang private, ruang publik, dan ruang service. } \\
\text { - } 1 \text { kamar tidur (private) } \\
\text { - } 1 \text { ruang serbaguna/ruang keluarga } \\
\text { (publik) } \\
\text { - Dapur (publik) }\end{array}$ & R. KELUARGA & $\begin{array}{l}\text { Hanya ada } 2 \text { shelter sementara yang } \\
\text { memiliki organisasi ruang berupa } 1 \text { kamar } \\
\text { tidur, } 1 \text { ruang serbaguna/ruang keluarga, } \\
\text { dan dapur. }\end{array}$ \\
\hline
\end{tabular}

Sumber : Dok. Pribadi

Melihat dari tabel diatas, fasilitas ruang service seperti dapur dan MCK masih kurang dipertimbangkan dalam pemberian kebutuhan ruang service pribadi untuk korban. Korban bencana yang tidak memiliki fasilitas dapur biasanya akan meletakkan dapur mereka di ruang serbaguna. Fasilitias dapur selama ini kebanyakan masih menggunakan fasilitas dapur umum. Sedangkan menurut Peraturan Kepala BNPB No. 11 Tahun 2008 tentang Pedoman Rehabilitasi dan Rekonstruksi Pasca Bencana, perbaikan minimal rumah untuk korban bencana adalah tersedianya :

- Ruang kegiatan fungsional minimal terdiri atas 1 ruang tidur,

- 1 ruang serbaguna, dan

- 1 ruang MCK.

Pada dasarnya, penyediaan shelter sementara untuk korban bencana sudah cukup sesuai dengan standar minimal, namun kebutuhan akan ruang service seperti dapur dan MCK pada shelter sementara masih menggunakan fasilitas umum. Menurut hasil wawancara dengan Dr. Nuraini Rahma Hanifa ahli kegempaan dan sekretaris di Pusat Unggulan Iptek (PUI-PT) Sains dan Teknologi Kegempaan ITB, penyediaan fasilitas MCK umum sangat tidak efektif untuk digunakan bersama, karena beberapa faktor yaitu :

- Pemilihan pintu toilet yang tidak layak, membuat pintu toilet mudah rusak dan bercelah, sehingga orang lain akan dengan mudah mengintip melalui celah tersebut. 
- Desain toilet umum hanya ada toilet basah, tidak tersedia toilet kering dan tidak dibedakan antara laki-laki dan wanita, sehingga ketika ada wanita yang ke toilet umum maka akan rawan merangsang lawan jenis dan memicu kasus pelecehan.

- Hal tersebut terjadi karena luas toilet yang disediakan masih tidak sesuai dengan standar kebutuhan ruang gerak manusia. Hal ini membuat pengguna akan kesulitan saat berganti pakaian, terlebih lagi tidak ada fasilitas toilet kering.

Faktor-faktor diatas tentunya mempengaruhi juga bagi korban penyandang disabilitas khususnya pengguna kursi roda. Jika toilet umum yang disediakan tidak sesuai dengan kebutuhan ruang gerak manusia maka toilet tersebut tidak aksesibel dan rancangan tidak mempertimbangkan kebutuhan penyandang disabilitas. Menurut hasil penelitian Raviandaru dan Roychansyah (2018), juga menjelaskan bahwa mayoritas korban bencana akan menambah fungsi ruang service pribadi pada hunian. Ini artinya berdasarkan alasan para penghuni shelter bahwa keberadaan sebuah aktivitas service dengan akses pribadi adalah menjadi keinginan dari setiap penghuni. Berdasarkan analisis di atas, maka penyediaan kebutuhan program ruang yang masih perlu dipertimbangkan kembali adalah pemberian ruang service pribadi seperti dapur dan toilet pribadi yang juga aksesibel bagi penyandang disabilitas.

\section{e. Relasi Ruang / Aksesibilitas}

Pada analisis aksesibilitas penulis menggunakan analisis Space Syntax. Pada tabel 1, convex spaces menjelaskan hubungan antar ruang melalui garis penghubung kemudian justified graph adalah yang membantu memberi visualisasi konfigurasi ruang. Ruang direpresentasikan dengan bentuk lingkaran dan hubungan ruang (link) dinotasikan sebagai garis yang menghubungkan lingkaran (Hiller, 2007:22).

Jika melihat hubungan antara convex space dan j-graph pada tabel 1, menunjukkan bahwa didalam shelter sementara terdapat relasi antar ruang. Relasi-relasi ruang tersebut di tunjukkan melalui kode disetiap ruang yang dihubungkan satu dengan yang lainnya, sehingga terbentuklah sebuah struktur relasi ruang. Space syntax mempergunakan konsep jarak yang disebut kedalaman (depth) yang diukur dalam langkah (step) yang disebut jarak topologis atau topological distance (Hillier et al: 1987). Jumlah ruang yang terhubung dihitung dengan mempergunakan konsep jarak yang disebut kedalaman atau depth. Apabila hanya memiliki jarak sebesar 1 langkah atau 1 step depth maka dikatakan terhubung secara langsung. Sesuai pada tabel diatas, maka pada analisis space syntax ini penulis akan melakukan pengukuran connectivity yang dilakukan untuk menemukan tingkat interaksi setiap ruang terhadap ruang-ruang yang berada di dekatnya. Dari tabel j-graph dapat dilihat bahwa terdapat 3 jenis 
konfigurasi yang terbentuk pada shelter sementara, berikut adalah nilai-nilai connectivity setiap konfigurasi :

Tabel 5. Nilai Connectivity pada Aspek Aksesibilitas Ruang Shelter Sementara

\begin{tabular}{|c|c|c|}
\hline No. & Nilai Connectivity & Keterangan \\
\hline 1. & & $\begin{array}{l}\text { Ruang A tidak memiliki hubungan ruang satu dengan lainnya, sehingga nilai } \\
\text { connectivity }=0 \\
\text { Maka dapat disimpulkan bahwa ruang A tidak memiliki konfigurasi ruang, karena tidak } \\
\text { memiliki pembagian ruang seperti ruang private, ruang publik, ataupun ruang service. }\end{array}$ \\
\hline 2. & & $\begin{array}{l}\text { - Ruang A hanya terhubung secara langsung dengan ruang B, sehingga nilai } \\
\text { connectivity }=1 \\
\text { - Sebaliknya, ruang B juga terhubung secara langsung dengan ruang A, sehingga } \\
\text { nilai connectivity = } 1 \\
\text { Berdasarkan perhitungan tersebut, dapat disimpulkan bahwa ruang A dan B sama- } \\
\text { sama memiliki keterkaitan hubungan ruang dimana secara spasial dapat dengan } \\
\text { mudah dijangkau ruang-ruang lainnya dan dalam konfigurasi ruang cenderung berada } \\
\text { di "tengah" sistem. }\end{array}$ \\
\hline 3. & & $\begin{array}{l}\text { - Ruang A terhubung secara langsung dengan ruang } B \text {, dan } C \text { sehingga nilai } \\
\text { connectivity adalah } 1(\mathrm{~b})+1(\mathrm{c})=2 \\
\text { - Ruang } B \text { dan } C \text { masing-masing memiliki nilai connectivity yang sama dan masing- } \\
\text { masing hanya terhubung secara langsung dengan ruang } A \text {, sehingga nilai } \\
\text { connectivity }=1 \\
\text { Dari analisis tersebut ditemukan bahwa ruang A memiliki connectivity tertinggi } \\
\text { sedangkan ruang B dan } C \text { terendah. Secara visual, dapat diamati dalam j-graph pada } \\
\text { gambar } 13 \text { dimana ruang A berada di depan konfigurasi sehingga cenderung memiliki } \\
\text { hubungan ruang yang lebih banyak daripada ruang } B \text { dan } C \text {, dan lebih mudah } \\
\text { dijangkau ruang-ruang lainnya. }\end{array}$ \\
\hline
\end{tabular}

Sumber : Dok. Pribadi

Berdasarkan tabel diatas terkait dengan analisis space syntax, jika melihat dari nilai connectivitynya, maka dapat dikatakan bahwa ruang A sifatnya publik karena cenderung memiliki nilai connectivity tinggi, yaitu memiliki hubungan ruang yang lebih banyak, dan lebih mudah dijangkau, sedangkan ruang $B$ dan $C$ sifatnya lebih private. Jika dilihat dari organisasi ruangnya, ruang A terletak didepan titik masuk sehingga aksesnya mudah, sedangkan ruang B dan C letaknya didalam dan lebih privasi untuk lawan jenis, atau yang sudah berkeluarga namun secara umum sama-sama mudah dijangkau karena letaknya berdekatan. 
Dari ketiga jenis konfigurasi ruang diatas, konfigurasi ruang nomor tiga adalah yang paling layak untuk diterapkan dalam shelter sementara karena sudah terbagi program ruangnya, sehingga ruang privasi bagi penghuni dapat terpenuhi, selain itu lebih ramah huni bagi calon penghuni kelompok rentan seperti lansia dan penyandang disabilitas sehingga mereka dapat dirawat dengan mudah karena akses ruang satu dengan yang lainnya saling terhubung dan berdekatan. Adanya pembagian ruang juga sangat meminimalisir adanya resiko kekerasan, pencurian, pelecehan seksual, dan eksploitasi karena laki-laki dan perempuan yang bukan berasal dari keluarga inti yang sama tidak perlu lagi berbagi shelter, oleh karena itu shelter sementara jauh lebih aman dibandingkan dengan shelter darurat yang tidak memiliki konfigurasi ruang. Namun sayangnya, rata-rata bangunan shelter sementara diatas hanya menerapkan dua konfigurasi ruang, yaitu berupa satu kamar tidur, dan ruang serbaguna/ruang keluarga untuk ditinggali 4-5 orang. Hal tersebut dirasa kurang memenuhi kebutuhan ruang untuk 4-5 orang, maka berdasarkan analisis space syntax tersebut dapat dikatakan bahwa bangunan shelter sementara ini adalah bangunan yang dirancang secara sederhana dan sementara.

\section{f. Material}

Seperti yang dijelaskan pada Panduan Shelter untuk Kemanusiaan, material bangunan menjadi salah satu daftar penting pertimbangan kebudayaan. Maka material yang diusulkan harus sesuai dengan konteks kebudayaan setempat. Untuk memastikan bahwa shelter tersebut memiliki kesesuaian budaya, sangat penting untuk melibatkan masyarakat terdampak dalam tiap tahap proses perancangan dan implementasi. Pemilihan material yang sesuai dengan tujuan pembangunan shelter, tahan lama, ramah lingkungan, terjangkau dan dapat diterima secara budaya adalah salah satu tantangan besar dalam shelter. Berikut adalah jenis material yang diterapkan pada shelter sementara yaitu :

Tabel 6. Nilai Connectivity pada Aspek Aksesibilitas Ruang Shelter Sementara

\begin{tabular}{|l|l|l|}
\hline No. & \multicolumn{1}{|c|}{ Jenis Material } & \multicolumn{1}{c|}{ Keterangan } \\
\hline 1. & Material Alam & 4 dari 8 shelter sementara sudah menggunakan material lokal ramah lingkungan \\
& & seperti bambu, daun rumbia dan kayu. \\
& & $\begin{array}{l}\text { Penggunaan material lokal ramah lingkungan hanya diterapkan dibeberapa daerah } \\
\text { tertentu saja. }\end{array}$ \\
\hline 2. & Material Bangunan & $\begin{array}{l}5 \text { shelter sementara lainnya menggunakan material bangunan seperti GRC, triplek, } \\
\text { dan baja ringan. }\end{array}$ \\
\hline
\end{tabular}

Sumber : Dok. Pribadi 
Jenis material yang digunakan pada shelter sementara tentunya memiliki kelebihan dan kekurangannya masing-masing, contohnya kekurangan yang dirasakan penghuni saat menggunakan material alam adalah merasa privasi masih kurang walaupun sudah beda bilik karena materialnya yang kurang kedap suara.

Beberapa hal penting yang perlu diperhatikan dalam memilih material shelter dalam buku The Sphere Project yaitu,

a. Ketika sumber daya alam tersedia, pembuatan permukiman warga sementara harus dilaksanakan dengan meminimalkan kerusakan lingkungan sekitarnya.

b. Permukiman yang dikelola baik dengan ukuran lebih besar tetapi berjumlah lebih sedikit mungkin akan lebih ramah lingkungan dalam jangka panjang dibandingkan dengan permukiman yang berukuran lebih kecil tetapi dalam jumlah lebih banyak, tersebar, yang tidak dapat dikelola dan diawasi dengan mudah.

c. Dampak terhadap lingkungan dari pemilihan sumber daya dari lingkungan alam perlu dikaji, seperti air, kayu bangunan, pasir, tanah, dan rumput, juga bahan bakar untuk pembakaran batubata dan genteng. Sumber pasokan alternatif atau tambahan mungkin mendukung ekonomi lokal dan mengurangi dampak buruk pada lingkungan alam setempat. Penggunaan sumber-sumber yang beragam dan penggunaan kembali bahan-bahan sisa bangunan yang berhasil dikumpulkan, bahanbahan dan proses produksi alternatif. Tindakan-tindakan ini harus dikombinasikan dengan praktikpraktik mitigasi, misalnya penanaman kembali pohon-pohon secara seimbang.

Maka berdasarkan fakta temuan diatas, pemilihan material pada shelter sementara perlu dipertimbangkan dengan matang dan disesuaikan dengan budaya setempat. Keterlibatan masyarakat setempat secara aktif dari tahap perencanaan sampai pembangunan turut menghasilkan desain yang sesuai dan menjawab kebutuhan serta kebiasaan penghuninya. Hal tersebut sesuai dengan penelitian Prasetyo, Tobing, dan Budiyuwono (2018) yang menghasilkan temuan bahwa dari sisi lingkungan atau ekologis, penggunaan material lokal serta pemberdayaan sumber daya yang ada di lingkungan sekitar pemukiman membuat desain hunian ini dapat melekat dengan kondisi lingkungan dan alamnya.

\section{g. Sistem Konstruksi}

Sistem konstruksi yang digunakan dalam shelter sementara adalah rumah tahan gempa baik itu untuk bencana gempa bumi maupun tsunami. Rumah tahan gempa diaplikasikan agar menghindari dari 
ancaman bencana dimasa yang akan datang. Struktur yang digunakan adalah sistem knockdown yaitu dapat dibongkar pasang dan dipakai ulang. Menurut buku panduan Shelter untuk Kemanusiaan berikut adalah jenis konstruksi bangunan yang dapat mempengaruhi kekuatan dan kesatuan struktur :

Tabel 7. Bentuk Struktur Bangunan

\begin{tabular}{|l|l|l|}
\hline No. & \multicolumn{1}{|c|}{ Keterangan } \\
\hline 1. & $\begin{array}{l}\text { Tata letak denah lantai geometris sederhana seperti bujur sangkar dan } \\
\text { persegi pendek, lebih kuat daripada bentuk rumit seperti persegi } \\
\text { panjang, halaman dalam rumah, bangunan berbentuk silang, } \mathrm{U} \text { atau } \mathrm{L} .\end{array}$ \\
\hline 2.
\end{tabular}

Sumber : Panduan Shelter untuk Kemanusiaan

Jika melihat aspek sistem konstruksi pada tabel 1, secara umum ke 8 shelter sementara sudah menerapkan tata letak denah lantai berbentuk bujur sangkar atau persegi pendek yang artinya sudah memiliki struktur bangunan yang kokoh. Kemudian pada rancangan atap ke 8 shelter sementara menggunakan atap pelana dengan kemiringan ganda. Atap pelana dengan kemiringan ganda bagus untuk daerah dengan curah hujan tinggi, dan relatif mudah dibangun (Panduan Shelter untuk Kemanusiaan). Maka dalam praktik pembangunan dapat berarti rancangan atap harus dipertimbangkan ulang di area tertentu jika kerusakan disebabkan oleh hujan atau angin.

Dari hasil analisis berbagai aspek diatas, menunjukkan bahwa program penyediaan shelter sementara di Indonesia memiliki karakter sebagai berikut : a.) Jenis bencana yang menimpa korban bencana adalah jenis bencana besar dan mendadak seperti tsunami dan gempa bumi sehingga berdampak pada hilangnya rumah tinggal, b.) Bentuk dan Jenis, terdapat 2 tipe antara lain adalah organisasi bentuk linier dimana hunian dibangun bersama-sama dalam satu deret dengan jenis rumah panggung, dan hunian terklaster / tersebar dengan jenis rumah tapak (tunggal), c.) Ukuran shelter sementara sudah mencukupi kebutuhan kapasitas untuk satu keluarga (4-5 orang), d.) Program Ruang, pola tata ruang pada shelter sementara secara umum terbagi menjadi dua kriteria yaitu : (1.) Ruang publik, dan ruang private, serta (2.) Ruang publik, ruang private, dan ruang service. Posisi zona ruang publik secara umum berada di bagian depan, sedangkan ruang private dan service berada di bagian tengah ke belakang. e.) Aksesibilitas, semakin dalam ruangnya semakin private, sedangkan ruang yang berada didepan 
cenderung sebagai ruang publik karena memiliki hubungan ruang yang lebih banyak. Secara umum program ruang pada shelter sementara memiliki aksesibilitas yang mudah karena saling terhubung ruang satu dengan yang lainnya. f.) Material, terdapat 2 jenis material yang digunakan yaitu material alam seperti kayu, bambu, daun rumbia, serta material bangunan seperti GRC, triplek, kalsiboard, dan baja ringan, g.) Sistem Konstruksi, secara umum shelter sementara sudah menerapkan struktur bangunan tahan gempa, dan modular (bongkar pasang), serta bangunan juga berbentuk bujur sangkar / persegi pendek sehingga struktur lebih kokoh.

\section{PENUTUP}

Berdasarkan hasil analisis yang sudah dipaparkan diatas maka dapat disimpulkan bahwa aspek yang perlu dipertimbangkan kembali dalam memenuhi kebutuhan penghuni adalah aspek program ruang, khususnya bagi keluarga yang memiliki jumlah keluarga yang banyak perlu menerapkan minimal tiga program ruang untuk satu keluarga yang berjumlah lebih dari 4-5 orang, selain itu pemberian ruang service pribadi seperti dapur dan toilet pribadi juga perlu diterapkan sehingga dapat mempermudah penghuni khususnya bagi penyandang disabilitas, karena keberadaan sebuah aktivitas service dengan akses pribadi adalah menjadi keinginan dari setiap penghuni. Pemberian MCK umum selama ini masih kurang memperhatikan kebutuhan kelompok rentan, khususnya penyandang disabilitas dimana ruang gerak untuk masuk dan keluar bagi pengguna kursi roda tidak aksesibel karena ukurannya yang kecil. Secara umum shelter sementara memiliki karakter bangunan yang sederhana karena jangka waktu penggunaannya pun bersifat sementara.

Beberapa faktor yang mempengaruhi karakter pada shelter sementara yaitu : 1.) Profil bencana, secara umum bencana yang terjadi adalah bencana alam berat yang terjadi secara cepat/mendadak seperti gempa bumi dan tsunami, sehingga membutuhkan program shelter dalam jumlah yang besar dan cepat, oleh karena itu bentuk pada shelter sementara cenderung linier dimana hunian dibangun bersama-sama dalam satu deret guna mepersingkat waktu pembangunan. 2.) Tipologi perumahan dan pemukiman sebelum bencana, cara orang tinggal sebelum bencana akan secara langsung mempengaruhi kebutuhan shelter mereka saat terjadi bencana, pun jenis bantuan yang sesuai, yang akan mendukung mereka menuju pemulihan. 3.) Tipologi perumahan dan pemukiman setelah bencana, karena kehilangan rumah tinggal maka dampaknya banyak yang akan mencari perlindungan 
dalam salah satu bentuk shelter. 4.) Fakor-faktor lingkungan, seperti perbedaan iklim dapat mempengaruhi kebutuhan shelter agar rancangan shelter sesuai dengan iklim setempat, 5.) Konteks sosial budaya, baik dalam pemilihan material bangunan, penentuan program ruang dalam shelter, dan rancangan shelter.

Maka dari analisis karakter fisik tersebut, saran program penyediaan shelter bagi korban bencana alam adalah :

1. Menghindari tempat - tempat berpotensi terkena bencana alam seperti daerah rawan gempa, tsunami, banjir, dan longsor, yaitu dengan cara tidak menempatkan bangunan di tempat-tempat rawan bencana.

2. Dalam banyak kasus, bangunan yang akan didirikan di tempat-tempat yang berpotensi terjadi bencana alam seperti gempa bumi, maka struktur bangunan harus dirancang dengan bangunan yang tahan gempa. Untuk daerah-daerah yang berpotensi terkena banjir maka bangunan harus dibuat dengan struktur panggung sebagai upaya menghindari terpaan air atau ancaman bencana dimasa mendatang, seperti banjir.

3. Beberapa bencana alam dapat diseimbangkan dengan menerapkan rekayasa keteknikan, seperti di daerah-daerah berlereng dan berpotensi longsor, yaitu dengan cara membuat kemiringan lereng menjadi landai, serta bangunan yang akan didirikan dapat menggunakan pondasi tiang pancang sampai kebagian lapisan tanah yang stabil, sehingga kemungkinan longsor menjadi kecil.

4. Perlu adanya pemberian ruang service berupa toilet pribadi, jika tidak memungkinkan maka perlu adanya pembeda antara toilet laki-laki dengan perempuan, selain itu rancangan toilet harus sesuai dengan ukuran ruang gerak manusia khususnya bagi kelompok rentan.

5. Jika menggunakan material lokal yang ramah lingkungan, maka perlu adanya tindakan mitigasi bencana seperti penanaman pohon kembali agar sumber daya alam tetap terpelihara dengan seimbang.

6. Sangat penting untuk mempertimbangkan lingkungan setempat, budaya, dan iklim setempat dalam membangun sebuah shelter.

7. Melibatkan masyarakat setempat dalam setiap tahap proses perancangan serta implementasi program shelter sangat penting untuk memastikan shelter dapat sesuai secara akurat dengan kebutuhan dan keinginan penghuni, tidak terkecuali kelompok rentan. 
8. Jika memungkinkan, bantuan shelter harus dapat digunakan kembali, dapat dikemas kembali, dapat didaur ulang atau mudah terurai secara alamiah.

\section{DAFTAR PUSTAKA}

Angkasa, Z. (2018). Penerapan konsep arsitektur rumah panggung di lingkungan perkotaan. Arsir, 1(2), 175-183.

Affisa, F. S., \& Djunaedi, I. A. (2014). Efektivitas kawasan hunian sementara sebagai media pemulihan pengungsi pasca bencana merapi 2010 studi kasus pada kawasan hunian sementara plosokerep, gondangpusung, banjarsari, dan gondanglegi. Doctoral dissertation, Universitas Gadjah Mada.

Bencana, B. N. P. (2008). Peraturan Kepala BNPB No. 11 Tahun 2008 tentang Pedoman Rehabilitasi dan Rekonstruksi Pasca Bencana.

Ching, F. D., \& Dai-Kam, F. (1996). Arsitektur: Bentuk, ruang, dan tatanan. Erlangga.

Hanifa, Nuraini R. (2020). "Manajemen Bencana dan Penyediaan Shelter bagi Korban Bencana Alam". Hasil Wawancara Pribadi : 6 Februari 2020, Institut Teknologi Bandung.

Johnson. P A. (1994). The Theory of Architecture, Van Nostrand Reinhold Company. New York.

Sosial, Kementerian., dan Indonesia, Palang Merah. (2019). Panduan shelter untuk kemanusiaan. Jakarta : Kementerian Sosial Republik Indonesia

Sukada, B. (1989). Memahami arsitektur tradisional dengan pendekatan tipologi. Bandung.

iNews, Official. (2019, Desember 22). Setahun usai tsunami, ratusan warga pandeglang masih tinggal di hunian sementara [Video file]. Diakses dari https://www.youtube.com/watch?v=lbJkG3oCiyg

Rasyid, Satria Z. (2018, November 9). Huntara pengungsi lombok tergenang banjir. Diakses dari https://hariannusa.com/2018/11/09/huntara-pengungsi-lombok-tergenang-banjir/ 